\title{
ベンゼンスルホニル化/焱光光度検出ガスクロマト グラフィーによるー級アミンの定量
}

\author{
大類 諭, 片岡 洋行 ${ }^{\circledR}$, 宮本 好明, \\ 大塚 (竹田)貴美代，蒔田 政見*
}

( 1990 年 10 月 11 日受理)

\begin{abstract}
GC による一級アミンの選択的高感度尘量法を検討した. Hinsberg 反忍によりアミンをベンゼンス ルホニル誘導体へ変換した後， $50 \%$ 水酸化カリウム $-22.5 \%$ メタノール溶液中でへキサン抽出すること により一級アミンは一級アミンから完全に分離された。水相中に残存する一級アミンのベンゼンスルホ ニル誘導体は，酸性条件下ジエチルエーテルで抽出し，DB-1 キャピラリーカラムを用いる炎光光度検 出（FPD）-GCにより分析した。 ブチルアミンの誘導体化収率は $96.7 \pm 4.0 \%(n=3)$ であった. FPD-GC による一級アミンの検量線は誘導体化量として 20〜1000 ng の範囲で直線性を示した。 又, 検出限界は GC 注人量として約 10〜 $100 \mathrm{pg}$ であり，水素フレームイオン化検出-GC 法に比べ 20 倍以 上の感度を有することが分かった。
\end{abstract}

\section{1 緒言}

GC によるアミン類の分量法としては，一般にアシル

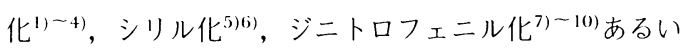

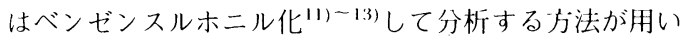
られている。しかし, 低級アミンの多くは水溶液性でし かも揮発性が问く, その㳬量的抽出及び濃縮が困難なた め, 反忍に無水条件を必要とするアシル化やシリル化す る方法は，これらアミンの微量分析には忍用できない。 一方, ジニトロフェニル化やベンゼンスルホニル化は水 溶液中で容易に行えるが, 前者では反忘収㴋が悪く7), 一級及び二級アミンが共存する試料ではそれらの分離が 林難である. Hinsberg ${ }^{1+1)}$ は，水酸化アルカリ存在下有 機溶媒抽出において，一級アミンのベンゼンスルホニル 誘導体がアルカリ塩を形成して水相に残存するのに対 し, 一級アミンのベンゼンスルホニル誘導体が有機溶媒 で抽出されることから，屾アミンを分別できることを報 告している. 又, Hamano ら (1)12) はこの手法を利用し て二:級アミンを炎光光度検出 (FPD)-GCにより選択的 に㳬量する方法を報告しているが，一級アミンについて は検討されていない。

著者らは，…級及び、級アミンの分別定量を月的とし

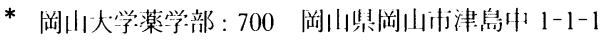

て Hinsberg 法を適用したところ, 一級及び—級アミン の各分画に相互のアミンが混人し，分別が不完全である ことが判明した，そこで本研究では，まず一級及び一級 アミンのベンゼンスルホニル誘導体を完全に分離する抽 出条件を検討し, 更に FPD-GC とキャピラリーカラム を用いて一級アミンを選択的かつ高感度に㳬量する方法 を確立した。

$$
2 \text { 実験 }
$$

\section{$2 \cdot 1$ 試 薬}

一級アミンとして, メチルアミン (MA), エチルア ミン, プロピルアミン, イソプロピルアミン及びイソブ チルアミンの塩酸壏を, 又ブチルアミン $(\mathrm{BA})$, ペンチ ルアミン, イソペンチルアミン, ヘキシルアミン, ヘプ チルアミン, オクチルアミン $(\mathrm{OA})$, シクロヘキシル アミン $(\mathrm{cHA})$, ベンジルアミン及び $\beta$-フェネチルアミ ン（PEA）の遊離型を用い，それぞれ精製水に浴かして $1 \mathrm{mg} / \mathrm{ml}$ のアミンを含む混合浴液とした。一.級アミン としては，ジメチルアミン（DMA）及びジエチルアミ ン（DEA）の壏酸塩を, 又ジプロピルアミン (DPA) 及びジブチルアミン（DBA）の遊離型を用い，それぞ れ精製水に溶かして $1 \mathrm{mg} / \mathrm{ml}$ のアミンを含む混合浴液 とした。これらの一級及び一.級アミンの標準溶液は密栓 して冷蔵保存しこれを用時希釈して用いた。 
内標準物質（I.S.）としては，和光純薬工業製残留農 薬試験用 $O, O$-ジメチル-O-(3-メチル-4-ニトロフェニル) チオリン酸 (MEP) を用い, $1 \mathrm{mg} / \mathrm{ml}$ の酢酸エチル溶 液として冷蔵保存し，これを用時希釈して用いた。

塩化ベンゼンスルホニル (BSC) は石津製薬製を用い た.

その他の試薬はすべて市販特級品を用いた。

\section{$2 \cdot 2$ GC 及び測定条件}

水素フレームイオン化検出器（FID）及びFPD 付き 鼠津ガスクロマトグラフ GG-14A 型を用いた。分離カ ラムは, J\&W 製 DB-1 (長さ $15 \mathrm{~m}$, 内径 $0.53 \mathrm{~mm}$, 膜 厚 $1.5 \mu \mathrm{m}$ )を朋いた。測走条件は, 注人口及び検出器 温度 $290^{\circ} \mathrm{C}$, カラム温度 $120^{\circ} \mathrm{C}$ から $280^{\circ} \mathrm{C}$ まで毎分 $10^{\circ} \mathrm{C}$ の开温, 窒素流量 $10 \mathrm{ml} / \mathrm{min}$ で行った。

\section{$2 \cdot 3$ 誘導体化操作}

アミン水溶液 $0.45 \mathrm{ml}$ (アミン 20 ～ $1000 \mathrm{ng}$ を含む) をスクリューキャップ付き試験管（岩城硝子製 10 $\mathrm{cm} \times 1.5 \mathrm{~cm}$ i.d.) に取り，これに $50 \%$ 水酸化カリウム $50 \mu \mathrm{l}$ 及び BSC $20 \mu \mathrm{l}$ を加えて公温で 15 分間振り混ぜ 機で振り混ぜる，反心液に $65 \%$ 水酸化カリウム $-30 \%$ メ夕ノール溶液 $1.5 \mathrm{ml}$ を加え最終濃度を水酸化力リウ ム $50 \%$, メ夕ノール $22.5 \%$ とし, ヘキサン $3 \mathrm{ml}$ で 2 回抽出して過剩の BSC を除く. 水相に $15 \%$ 塩酸 $4 \mathrm{ml}$ を加えて $\mathrm{pH}<1$ とし, 冷却後ジエチルエーテル $3 \mathrm{ml}$ で 2 回抽出する. $60^{\circ} \mathrm{C}$ 以下で浴媒を留去した後, 残留

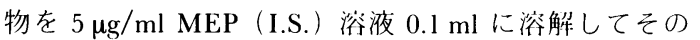
$1 \mu \mathrm{l}$ をGCに付す.

\section{$2 \cdot 4$ ベンゼンスルホニル誘導体のへキサン抽出によ る水相への残存率の測定}

$50 \mu \mathrm{g}$ の各アミンから得られたベンゼンスルホニル誘 導体にメタノ一ル及び水酸化カリウムを加えて全量 2 $\mathrm{ml}$ とし，ヘキサン $3 \mathrm{ml}$ で抽出する。遠心分離後，へキ サン相（二級アミン分画）と水相（一級アミン分画）に 分け，水相を更に塩酸酸性 $(\mathrm{pH}<1)$ としてジエチル エーテル $3 \mathrm{ml}$ で 2 凹抽出する。へキサン相及びエーテ ル相はそれぞ榕媒を留去した後, $1 \mathrm{mg} / \mathrm{ml} \mathrm{MEP}$ (I.S.) $0.1 \mathrm{ml}$ に溶解し, FID-GC 分析する. それぞれ の I.S.に対する爻アミン誘導体のピーク高さ比を求 め，へキサン相及び水相に残存するアミンの総量から水 相への残存率を算出する。

\section{3 結果及び考察}

\section{$3 \cdot 1$ 一級及び二級アミンの分離}

Hinsberg 法 $^{(4)}$ に従い-.-級及び一.級アミンの混液をべ ンゼンスルホニル化後, ヘキサン抽出して有機相(二級 アミン分画）と水相（一級アミン分画）に分け，水相を 更に塩酸酸性としてエーテル抽出し，冬抽出液中のアミ ンを FPD-GC 分析した. Fig. 1A，B に示すように，一 級アミン分画に DMA が，又一級アミン分画に $\mathrm{cHA}$ 及 び $\mathrm{OA}$ が一部混人し，一級及び、.級アミンの分離が不 完全であることが判明した。そこでへキサン抽出時，ア ルカリ濃度及び他の漁媒の添加を試みたところ，アルカ リ濃度の増加及びメタノールの添加により汕アミンの分 離が改善できることが分かった．Table 1 に示すように 水酸化カリウム濃度は，メ夕ノールが存在しないときは $60 \%$ で，又メタノール $20 \%$ を含む場合は $50 \%$ 以上で 汕アミンを分離できることが分かった。しかし，60\% の水酸化カリウム浴液中ではBSC が分解して生じたべ ンゼンスルホン酸カリウムが析出し，分相が林難であっ

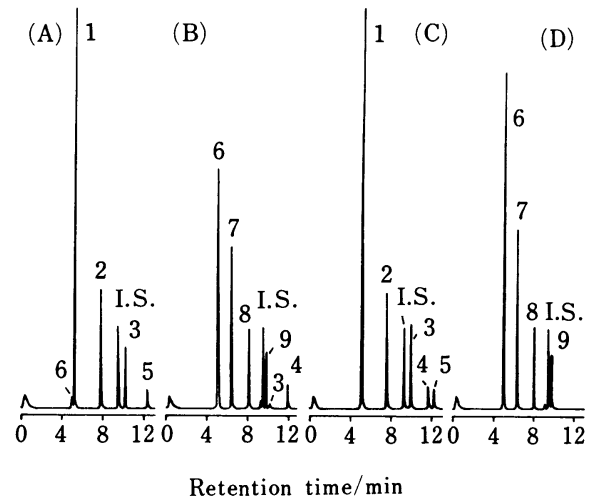

Fig. 1 Gas chromatograms obtained from primary and secondary amine fractions by Hinsberg and the proposed methods

(A) primary amine fraction and (B) secondary amine fraction by Hinsberg method, (C) primary amine fraction and (D) secondary amine fraction by the proposed method. GC conditions-Column: DB-1 $(15 \mathrm{~m} \times 0.53 \mathrm{~mm}$ i.d., $1.5 \mu \mathrm{m}$ film thickness $)$; Column temperature: programmed at $10^{\circ} \mathrm{C} / \mathrm{min}$ from $120^{\circ} \mathrm{C}$ to $280^{\circ} \mathrm{C}$; Injection and detector temperature : $290^{\circ} \mathrm{C} ; \quad \mathrm{N}_{2}$ flow rate: $10 \mathrm{ml} / \mathrm{min}$; Detector: FPD; Attenuation : $10 \times 128$. Peaks : $1=$ methylamine, $2=$ butylamine, $3=$ cyclohexylamine, 4 $=$ octylamine, $5=\beta$-phenylethylamine, $6=$ dimethylamine, $7=$ diethylamine, $8=$ dipropylamine, 9 $=$ dibutylamine, I.S. $=$ MEP 
Table 1 Effect of $\mathrm{KOH}$ concentration on the separation of benzenesulfonyl derivatives of amines by extraction with hexane

\begin{tabular}{ccccccccccc}
\hline \multirow{2}{*}{$\begin{array}{c}\text { MeOH, } \\
\%\end{array}$} & $\begin{array}{c}\text { KOH, } \\
\%\end{array}$ & MA & BA & OA & cHA & PEA & DMA & DEA & DPA & DBA \\
\cline { 3 - 10 } & 5 & 100 & 98.6 & 0 & 83.7 & 98.1 & 7.6 & 0 & 0 & 0 \\
\hline 0 & 10 & 100 & 100 & 0 & 85.9 & 99.0 & 2.7 & 0 & 0 & 0 \\
& 20 & 100 & 100 & 0 & 89.3 & 100 & 0.2 & 0 & 0 & 0 \\
& 30 & 100 & 100 & 65.1 & 93.1 & 100 & 0 & 0 & 0 & 0 \\
& 40 & 100 & 100 & 93.9 & 96.2 & 100 & 0 & 0 & 0 & 0 \\
& 50 & 100 & 100 & 96.7 & 99.3 & 100 & 0 & 0 & 0 & 0 \\
& 60 & 100 & 100 & 100 & 100 & 100 & 0 & 0 & 0 & 0 \\
& 5 & 100 & 100 & 5.8 & 87.1 & 100 & 24.1 & 1.4 & 0 & 0 \\
& 10 & 100 & 100 & 14.8 & 100 & 100 & 16.7 & 0 & 0 & 0 \\
& 20 & 100 & 100 & 47.1 & 100 & 100 & 5.7 & 0 & 0 & 0 \\
& 30 & 100 & 100 & 58.7 & 100 & 100 & 3.3 & 0 & 0 & 0 \\
& 40 & 100 & 100 & 82.0 & 100 & 100 & 0 & 0 & 0 & 0 \\
& 50 & 100 & 100 & 100 & 100 & 100 & 0 & 0 & 0 & 0 \\
& 60 & 100 & 100 & 100 & 100 & 100 & 0 & 0 & 0 & 0 \\
\hline
\end{tabular}

Table 2 Effect of $\mathrm{MeOH}$ concentration on the separation of benzenesulfonyl derivatives of amines by extraction with hexane

\begin{tabular}{ccccccccccc}
\hline \multirow{2}{*}{$\begin{array}{c}\text { KOH } \\
\%\end{array}$} & $\begin{array}{c}\text { MeOH } \\
\%\end{array}$ & MA & BA & OA & cHA & PEA & DMA & DEA & DPA & DBA \\
\cline { 3 - 10 } & 0 & 100 & 97.8 & 0 & 75.1 & 96.9 & 18.3 & 0 & 0 & 0 \\
& 10 & 100 & 98.2 & 0 & 80.5 & 97.4 & 30.0 & 0 & 0 & 0 \\
& 20 & 100 & 100 & 6.0 & 87.4 & 100 & 36.1 & 0 & 0 & 0 \\
& 30 & 100 & 100 & 11.2 & 91.8 & 100 & 49.6 & 6.1 & 0 & 0 \\
& 40 & 100 & 100 & 47.6 & 100 & 100 & 66.6 & 16.3 & 0 & 0 \\
& 50 & 100 & 100 & 71.1 & 100 & 100 & 80.4 & 32.1 & 0 & 0 \\
& 60 & 100 & 100 & 87.9 & 100 & 100 & 91.7 & 60.7 & 9.8 & 0 \\
& 0 & 100 & 100 & 86.6 & 91.9 & 100 & 0 & 0 & 0 & 0 \\
& 10 & 100 & 100 & 100 & 100 & 100 & 0 & 0 & 0 & 0 \\
& 20 & 100 & 100 & 100 & 100 & 100 & 0 & 0 & 0 & 0 \\
& 30 & 100 & 100 & 100 & 100 & 100 & 0 & 0 & 0 & 0 \\
& 40 & 100 & 100 & 100 & 100 & 100 & 12.7 & 0 & 0 & 0 \\
& 50 & 100 & 100 & 100 & 100 & 100 & 38.9 & 4.3 & 0 & 0 \\
& 60 & 100 & 100 & 100 & 100 & 100 & 47.9 & 9.8 & 0 & 0 \\
\hline
\end{tabular}

た.一方, Table 2 に亦すようにメ夕ノール濃度を増加 させると一級アミン及び低級の二級アミンは水相に残存 しやすくなるが，水陵化カリウム $50 \%$ 中でメ夕ノール 10〜30\%とすることにより岘アミンを完全に分離でき た. Fig. IC，Dは $50 \%$ 水酸化カリウム $-22.5 \%$ メ ノール漁液中でへキサン抽出して得られたクロマトグラ ムを示しており，一級及び一級アミンは完全に分離され ている.

\section{$3 \cdot 2$ 誘導体化}

一級アミンは Hinsberg 反心に従い，5\% 水酸化カリ ウム浴液中で进速か一走量的に BSC と反忍し, 安定な ベンゼンスルホニル誘導体へ変換され, その構造は GC-MS 分析により確認された. $N$-ブチルベンゼンス ルホンアミド槽品 (東京化成下.業製) との比較により得 られた $100 \mathrm{ng}$ の BA の全誘導体化操作を通しての誘導 体化収率は， $96.7 \pm 4.0 \%(n=3)$ であった. 又誘導体 化操作は約 30 分と比較的短特閂に行え, 多数の検体の 
同時処理も仃能であった。

\section{$3 \cdot 3$ GC 分析}

一級アミンのベンゼンスルホニル誘導体は分子内に $\mathrm{NH}$ 基を有するため, パックドカラムを用いるとカラム 吸着を起こしやすく，感度も低下することが分かった. そこで不活性で熱多”定性に優れた浴融シリカキャピラ リーカラムを为いたところ，これらの問題は解決し良好 なクロマトグラムが得られた．Fig. 2 はそれぞれ 200

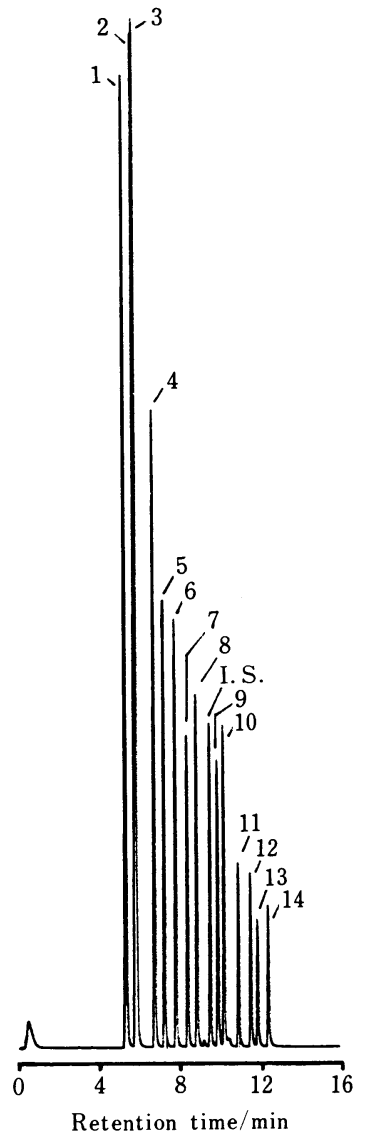

Fig. 2 Gas chromatogram obtained from 14 primary amines

GC was performed with the same conditions as in Fig. 1. Each peak represents $2 \mathrm{ng}$ of amine. Peaks : $1=$ methylamine, $2=$ ethylamine, $3=$ isopropylamine, $4=$ propylamine, $5=$ isobutylamine, 6 = butylamine, $7=$ isopentylamine, $8=$ pentylamine, 9 $=$ hexylamine, $10=$ cyclohexylamine, $11=$ heptylamine, $12=$ benzylamine, $13=$ octylamine, $14=\beta$ phenylethylamine, I.S. $=$ MEP
Table 3 Linear regression data for some primary amines

\begin{tabular}{lcc}
\hline Amine & Regression line & $r$ \\
\hline MA & $\log y=1.926 \log x-3.857$ & 0.9963 \\
BA & $\log y=1.647 \log x-3.586$ & 0.9953 \\
OA & $\log y=1.442 \log x-3.603$ & 0.9928 \\
cHA & $\log y=1.604 \log x-3.596$ & 0.9967 \\
PEA & $\log y=1.421 \log x-3.610$ & 0.9955 \\
\hline
\end{tabular}

$y=$ peak height ratio, $x=$ amount (ng) of each amine, $r$ : correlation coefficient ; No. of data : 24

$\mathrm{ng}$ を含む 14 種の一級アミン浴液から得られたクロマ トグラムを示しているが，いずれも対称性の良いピーク として溶出した。 20,50,100, 200,500,1000 ngの备ア ミンを含む一級アミン標準浴液を誘導体化し, MEP (I.S.) $500 \mathrm{ng}$ を加えて得られた検量線は，﨩対数プロ ットにより良好な㨁線性を示した（Table 3). 又, FPD-GC による MA，BA，OA，cHA 及び PEA の検出 限界は GC 注入量としてそれぞれ約 10,50,100, 50, 100 pg であり，FID-GC の場合に比べ 20 倍以上の感度を 有することが分かった。本法を用いれば，アミノ酸のア ミノ基も同様にベンゼンスルホニル化されるが，カルボ キシル基が遊離状態であるためエーテル抽出されず，ク ロマトグラム上にピークは全く検出されなかった．又， 農薬なよ゙の脂溶性の含硫化合物も誘導体化過程でへキサ ン抽出によりュ級アミンと共に抽出除去できることか ら，一級アミンを選択的に分析できることが分かった。 以上の結果から，キャピラリ一カラムと FPDを用いる ことにより, ng レベルの一級アミンを選択的かつ高感 度に定量できることから, 生体試料, 食品試料, 噮境試 料などの分析にも十分適用できると考えられ, 現在検討 中である.

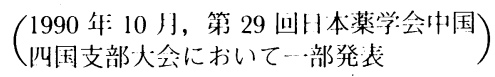

\section{文献}

1) W. J. A. VandenHeuvel, W. L. Gardiner, E. C. Hornig: Anal. Chem., 36, 1550 (1964).

2) J. A. Corbin, L. B. Rogers : Anal. Chem., 42, 974 (1970).

3) T. Walle, H. Ehrsson: Acta Pharm. Suecica, 8, 27 (1971).

4) M. Dalene, G. Skarping : J. Chromatogr., 331, 321 (1985).

5) W. J. A. VandenHeuvel: J. Chromatogr., 36, 354 (1968).

6) N. Mahy, E. Gelp:J. Chromatogr., 130, 237 (1977). 
7) E. W. Day, T. Golab, J. R. Koons : Anal. Chem., 38, 1053 (1966).

8）馬場貞雄, 羿谷正: 郎: 薬誌, 89, 1704 (1969).

9) S. Baba, I. Hashimoto, Y. Ishitoya : J. Chromatogr., 88, $373(1974)$.

10）古賀 実, 秋山高, 篠原亮太: 分析化学, 30, 745 (1981).
11) T. Hamano, A. Hasegawa, K. Tanaka, Y. Matsuki : J. Chromatogr., 179, 346 (1979).

12) T. Hamano, Y. Mitsuhashi, Y. Matsuki : Agric. Biol. Chem. (Tokyo), 45, 2237 (1981).

13) A. Terashi, Y. Hanada, A. Kido, R. Shinohara : J. Chromatogr., 503, 369 (1990).

14) O. Hinsberg: Chem. Ber., 23, 2962 (1890).

$\hat{w}$

Determination of primary amines by benzenesulfonylation/GC with flame photometric detection. Satoshi Ohrul, Hiroyuki Kataoka, Yoshiaki Miyamoro, Kimiyo Ohtsuka (nee TAKeda) and Masami Makita (Faculty of Pharmaceutical Sciences, Okayama University, 1-1-1, Tsushima-naka, Okayama-shi, Okayama 700)

A selective and sensitive method for the determination of primary amines by GC is described. After benzenesulfonylation of amines by Hinsberg reaction, primary amines were completely separated from secondary amines by extraction with hexane in $50 \%$ potassium hydroxide- $22.5 \%$ methanol solution. Benzenesulfonyl derivatives of primary amines in acidic aqueous layer were extracted by diethyl ether, and analyzed by GC with flame photometric detection (FPD-GC) using a DB-1 capillary column. Derivatization yield of butylamine was $96.7 \pm 4.0 \% \quad(n=3)$. By FPD-GC, the calibration curves of amines were linear in the range of $20 \sim 1000 \mathrm{ng}$ for the derivatives and the detection limits were about $10 \sim 100 \mathrm{pg}$ as injection amounts, which were above 20 times more sensitive than that obtained by GC with flame ionization detection.

(Received October 11, 1990)

\section{Keyword phrases}

gas chromatographic determination of primary amines; flame photometric detection of primary amines as their $\mathrm{N}$-benzenesulfonyl derivatives; separation of primary and secondary amines. 